Anna-Lise Laursen og Sven Tarp:

\title{
Orlando Galindo: Dansk spansk fagordbog (teknisk forlag a-s, 1979) og Dansk-spansk erhvervs- og фkono- miordbog (GTO Forlag, 1989)
}

Fagordbøger er oppe i tiden. Ingen tvivl om det. Med videnskabens og teknikkens udvikling vokser behovet for opslagsværker, hvor man med en let tilgang kan orientere sig i denne forunderlige verden. En sandhed, der gælder for både lægfolk og specialister.

Samtidig vokser også behovet for to-sprogede fagordbøger. Hvad enten man kan lide det eller ej, så betyder de voksende internationale forbindelser på alle områder, at behovet for faglig kommunikation mellem forskellige kulturer og sproggrupper øges. Ikke mindst Spaniens indhvirvlen i de europæiske stormagtsdrømme stiller krav om, at der udarbejdes pålidelige ordbøger til sprogparret dansk-spansk, såvel almensproglige som faglige.

Ser man kvantitativt på det, kan man lykkeligvis konstatere, at spansk med hensyn til to-sprogede fagordbøger ikke er et så forsømt område, som man kunne forvente. Hele tre, snart fem ordbøger af denne type er på markedet: Svend Jochumsen: Teknisk ordbog, dansk spansk (1983); Torben Henriksen: Spansk-dansk juridisk ordbog (1991); I.M. Crewe/ A.D. Mogensen: Handelsfaglig ordbog, dansk-spansk (1991); samt de to, som er emnet for denne artikel: Orlando Galindo: Dansk spansk fagordbog (1979) og Dansk-spansk erhvervs- og фkonomiordbog (1989).

Hvorfor anmelde to ordbøger, som allerede har flere år på bagen? Og hvorfor anmelde dem samlet?

Hertil gives der flere grunde. For det første er kritik og vurdering af de eksisterende ordbøger en af de vigtige opgaver for den teoretiske fagleksikografi, som er ved at udvikle sig i Danmark. Det er vigtigt at give brugerne en forståelse for, hvilke fejl og svagheder (og tilmed fælder) de kan forvente hos de enkelte ordbøger. Udviklingen af denne kritiske sans bør fremover være en langt mere integreret del af undervisningen, i det mindste på de læreanstalter, der uddanner professionelle oversættere. Desuden bidrager kritikken til at udvikle nye og forbedrede koncepter for fremtidens ordbøger. 
En anden grund til denne forsinkede anmeldelse er, at Galindo netop har udsendt en Dansk fransk erhvervs- og фkonomiordbog, der ser ud til at være en tro oversættelse af den tilsvarende dansk-spanske (se Grete Duvås anmeldelse i dette nummer af Hermes).

Og endelig fremgår det af Galindos forord til 1989-ordbogen, at såvel den som fagordbogen fra 1979 er et resultat af en slags tvedeling af et større, fælles manuskript: »Det viste sig imidlertid, at manuskriptets omfang vanskeliggjorde dets udgivelse, hvorfor det blev nødvendigt at reducere antallet af opslag og eksempler... Men det tiloversblevne materiale gik naturligvis ikke i glemmebogen...« Det vil derfor ikke være urimeligt at anmelde ordbøgerne samlet.

\section{Generelle bemærkninger}

For en hvilken som helst ordbog gælder det, at brugerens behov må stå i centrum. Ordbogen skrives ikke for at tilfredsstille forfatterens egne lyster, ligesom den heller ikke kun må sigte på at score kassen.

Men for at skrive for brugeren, må man først kende eller definere ham. Det første spørgsmål, der rejser sig i denne forbindelse, er brugerens modersmål. Er det dansk eller spansk? Det er klart, at en bruger med dansk som modersmål har behov for langt flere sproglige (indbefattet grammatiske) oplysninger på målsproget end en bruger, der har denne kompetence på spansk. Omvendt vil en spansk bruger have behov for flere lemmata og kollokationer (samt andre sproglige angivelser) på udgangssproget end en dansk bruger, der har modersmålskompetence og f.eks. gennem sit kendskab til synonymer kan finde svar på sine spørgsmål under andre opslagsord. Ordbogen må så at sige strikkes sammen på forskellige måder, alt efter om brugeren har dansk eller spansk som modersmål. Skulle man tage hensyn til begge brugergrupper, måtte konsekvensen være mastodontens genopstandelse i form af en ordbog, hvad der bestemt ikke er tilrådeligt.

Det fremgår ingen steder i Galindos to ordbøger, hvem der i denne forbindelse er målgruppen. I begge er omslagstitel, forord og forkortelsesliste/mønt- og landeoversigt affattet på både dansk og spansk, hvad der antyder et forsøg på at sætte sig over begge stole. Derimod er brugervejledningen kun skrevet på dansk, hvad der taler for det modsatte synspunkt. Ser man endelig på lemmata, ækvivalenter og de tilsvarende (manglende) kollokationer og sproglige oplysninger, ligner det snarere et halvhjertet forsøg på at sætte sig mellem de to stole, uden at henvende sig til nogen som helst. 
Det næste spørgsmål, der rejser sig i forbindelse med målgruppen, er forholdet ekspert-novice. På dette punkt adskiller fagleksikografien sig fra den »almensproglige « leksikografi. Forudsætter vi, at brugerens modersmål er dansk, kan man groft dele brugerne op i fire hovedgrupper: 1) Personer med ringe kendskab til det pågældende fagsprog og ringe kendskab til målsproget. 2) Personer med ringe kendskab til det pågældende fagsprog og godt kendskab til målsproget. 3) Personer med solidt kendskab til det pågældende fagsprog og ringe kendskab til målsproget. 4) Personer med solidt kendskab til det pågældende fagsprog og godt kendskab til målsproget.

Det er indlysende, at disse forskellige brugergrupper kræver meget forskelligartede oplysninger, for at ordbogen fuldt ud kan tjene dem som et nyttigt redskab. Ringe kendskab til målsproget kræver langt flere sproglige oplysninger, ligesom ringe kendskab til fagsproget kræver oplysninger af faglig (encyklopædisk) art. Af økonomiske årsager kan det for sprogparret dansk-spansk være rimeligt at indbefatte alle disse brugertyper i samme ordbog, men det forudsætter, at man disker op med de nødvendige oplysninger. Endnu engang må vi konstatere, at Galindo har ladet springskoene ligge hjemme og er hoppet over, hvor gærdet er lavest. En forbløffende mangel på såvel sproglige som encyklopædiske oplysninger gør, at ingen af de fire brugertyper kan søge trøst i hans ordbøger (måske med en vis opblødning for gruppe fire). Ud over ordklasser, køn og til en vis grad tal savner man totalt oplysninger om fleksionsmorfologiske uregelmæssigheder, syntaktiske afvigelser, ortografiske ændringer, kollokationer, synonymer og antonymer, samt encyklopædiske informationer. Man savner også helt eksempler. Med andre ord: stort set alt, hvad der er brug for til at skabe det nyttige værktøj, Galindo påberåber sig.

Problemet er imidlertid ikke, at der er skrevet et par ordbøger, som ikke henvender sig til nogen som helst. Problemet er snarere, at de begge falbyder deres tjenester til en endda meget bred vifte af brugere. I 1979ordbogen betegnes brugergruppen som »alle, som har med korrespondance, markedsføring, oversættelse, montage, instruktionskurser og igangsætning af industrielle anlæg m.v. at gøre«. Altså en uhyre bred målgruppe. Og i 1989-bogen drejer det sig om »alle, der har spansk som arbejdssprog «. Den tyske leksikograf Hausmann har en betegnelse for den slags pral: »ordbogskriminalitet«. Et svagere ord kunne vel også gøre det. Selv om det ikke er formildende, er problemet imidlertid, at Galindo ikke er ene om den slags opstyltede reklame, men har det til 
fælles med et stort antal fagordbøger, der prøver at sælge deres magre indhold på et pralende ydre. I spidsen for den danske afdeling af denne særlige afart af leksikografien ligger indtil videre rædselsværket $I F F$ fagordbog, der så at sige repræsenterer ordenes nøgendans hen over de tomme sider.

\section{Dansk spansk fagordbog (1979)}

Hvad er en fagordbog? Umiddelbart vil man synes, at det må være en ordbog, der ikke beskæftiger sig med almensproget, men med det omdiskuterede begreb »fagsprog «. Dette begreb dækker her i Danmark normalt teknisk, juridisk, økonomisk og evt. kommercielt sprog, som igen alt efter formålet kan underopdeles i en lang række fagsprog. Læser man det ovenfor citerede uddrag fra Galindos forord, fremgår det, at ordbogen dækker teknisk og økonomisk sprog, samt korrespondance. Allerede her viser det sig altså, at titlen er misvisende, idet juridisk sprog er udeladt. Naturligvis er det stadig en ordbog over fagsprog, men det kan da ikke være meningen, at man selv skal gætte, hvilket fagsprog det drejer sig om.

Går man imidlertid opslagsordene efter i sømmene, opdager man hurtigt, at det hovedsagelig drejer sig om tekniske udtryk. Bevares, der er da medtaget ord fra økonomisk sprog. Men hvorfor kan man f.eks. finde ord som afladedokumenter, eksport, forsendelsesomkostninger og remburs, når helt relevante og hyppigt brugte ord som anlфbshavn, beneficiant, bortfragter, fortolde, korrespondentbank og rembursrekvirent ikke er medtaget? En del af forklaringen kunne være, at Galindo faktisk har ønsket (selv om han ikke siger det) at indsnævre ordbogens område til alene at dække teknisk sprog, men at han er sluppet uhyre dårligt fra den allerede omtalte kløvning af sit oprindelige manuskript, idet alle de nævnte ord med undtagelse af bortfragter dukker op i erhvervs- og $\emptyset$ konomiordbogen ti år senere.

Accepterer man det synspunkt, at det i virkeligheden drejer sig om en teknisk ordbog, er man dog ikke kommet ud over problemerne. For en professionel oversætter viser det sig hurtigt, at det mest typiske opslag i Dansk spansk fagordbog er det forgæves opslag. Egentlig er det ikke underligt. Galindo oplyser selv, at ordbogen indeholder 55.000 lemmata. Ingen ved, hvor mange tekniske ord og udtryk, der findes på dansk. Men man regner det i hvert fald i hundrede tusinder. Og hvert år kommer der nye tusinder til. 55.000 ord vil således kun være en mindre brøkdel af det ordforråd, en potentiel bruger kan forventes at rådføre sig med ordbogen 
om. Det rejser imidlertid en række problemer. For det første må tekniske ordbøger af Galindos slags være mere beskedne i deres selvforherligelse. For det andet vil en bare nogenlunde udtømmende teknisk ordbog for sprogparret dansk-spansk være noget af et kæmpeprojekt, hvis ikke bare alle de tekniske termer, men også alle ledsagende oplysninger skulle medtages. Spørgsmålet om udarbejdelse af brancheordbøger for de mest relevante brancher stiller sig derfor på dagsordenen. Galindos Dansk spansk fagordbog er trods sine 55.000 opslagsord hverken det ene eller det andet.

Hører man til de heldige, der har fundet det ønskede opslagsord, står man nu over for den næste store hurdle, som man kunne kalde jagten på den forsvundne ækvivalent. Heller ikke her er man videre godt stillet. Ækvivalenter er der såmænd nok af. Nogle gange endda i form af et helt tag-selv-bord, som opdeles af kommaer, når ordene »almindeligvis har identisk betydning og kan anvendes valgfrit «, og af semikoloner, når de »ikke er helt identiske«. Det lyder besnærende, men snart opstår tvivlen. Lad os se på to eksempler:

rense depurar, limpiar, purificar opsuge absorber, aspirar

Depurar, limpiar og purificar kan her ligesom absorber og aspirar anvendes synonymt, dvs. de er identiske inden for et mere eller mindre begrænset område. De kan imidlertid ikke anvendes »valgfrit« og slet ikke i teknisk sprog. Man kan f.eks. ikke sige purificar una casa, ligesom limpiar el aire lydet uteknisk og skurrer i øret. På samme måde kan man ikke forestille sig aspirar brugt i forbindelse med trækpapir, der opsuger vand, mens absorber her ville være den helt rigtige løsning. Der er mange af denne slags eksempler, ligesom der er eksempler på inkonsekvent brug af tegnsætningen. Resultatet er uundgåeligt, at brugeren kommer i tvivl — også i alle andre tilfælde.

En løsning kunne være, at man i forbindelse med ækvivalenten bragte betydningsadskillende markeringer, f.eks. som de 77 forkortelser for forskellige tekniske underområder, som Galindo yderst karrigt strør om sig med i løbet af bogens 440 sider. Men heller ikke dette ville være en optimal løsning, i det mindste ikke for den novice, der ikke er velbevandret i det pågældende fagområde. Lad os f.eks. tage aut, som dækker automobil. Hvis man nu i en bil har et oversættelsesproblem omkring en lygte, en startmotor, en benzinmotor, et kugleleje, en overfladebehandling osv., skal man så søge dette under aut (automobil), eller under el (elektricitet), elk (elektronik), mek (mekanik), mot (motor) eller mal 
(maling). Den teknisk ukyndige vil være i vildrede, og kun uddybende encyklopædiske (tekniske) oplysninger vil sætte vedkommende i stand til at finde den rigtige ækvivalent. På dette område adskiller fagordbogen sig afgørende fra den almensproglige ordbog. Imidlertid har problemet endnu ikke været behandlet i den metaleksikografiske litteratur. Og Galindos ordbog er da heller ikke på dette punkt værre end det store flertal af fagordbøger. Men indtil problemet bliver løst i teori og praksis, vil fagordbøgerne ikke leve op til kravene fra den brede brugerskare.

Sammenfattende kan man sige, at man skal være intet mindre end en Indiana Jones for at finde den ønskede ækvivalent. Og finder man den endelig, vil tvivlen nage én som følge af den usikkerhed, der er skabt gennem de mange forgæves opslag. Alt i alt ikke en særlig gunstig brugersituation.

\section{Dansk-spansk erhvervs- og økonomiordbog (1989)}

Der er i sandhed behov for en dansk-spansk ordbog inden for det merkantilt- $\varnothing$ konomiske felt. Oversættere og spanskstuderende, der beskæftiger sig med erhvervssprog, har hidtil måttet klare sig med de eksisterende almensproglige ordbøger, hvor der findes et sporadisk udvalg af $\varnothing$ konomiske udtryk. Initiativet til at udarbejde og publicere en ordbog af denne art er derfor prisværdigt og yderst velkomment.

Grundlaget for ordbogen er ifølge forordet forfatterens private optegnelser fra hans mangeårige oversættervirksomhed i forbindelse med store projekter i den spansk-talende verden. Som tidligere nævnt er udgangspunktet for ordbogen det materiale, som blev frasorteret ved fagordbogens udsendelse i 1979. Forfatteren har ud over dette materiale medtaget nye områder fra sin oversættervirksomhed, idet hensigten nu er at dække »jura, økonomi, regnskabslære, bankvirksomhed m.v.«

Herudover har forfatteren indlemmet »yderligere emnekredse, især vedrørende socio- $\varnothing$ konomiske aspekter «, der angiveligt skulle være relevante på grund af Spaniens indtræden i EF. Som det fremgår af ovenstående, er det et noget ambitiøst udvalg af emner, forfatteren vil dække i en enkelt ordbog: hele det $\varnothing$ konomiske univers (hvorfor i $\varnothing$ vrigt skille regnskabslære og bankvirksomhed ud?), forretningsverdenen plus den juridiske og socio-økonomiske sfære. Men ordbogens titel tyder på en indskrænkning af de perifere emnekredse, således at man kun kan forvente de delområder medtaget, der har direkte relation til erhverv og $\varnothing$ konomi.

Bogen indholder »henved 25.000 indgangsord og eksempler« og hen- 
vender sig som tidligere nævnt til »alle, der har spansk som arbejdssprog «. Med hensyn til eksemplerne er dette nu lidt af et postulat. Der forekommer i nogle af artiklerne diverse angivelser:

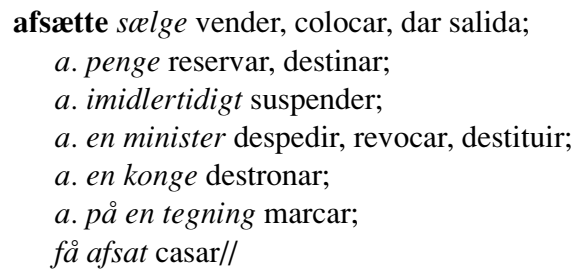

Det drejer sig i alle tilfælde om betydningsadskillende markeringer til indgangsordet. Deciderede danske eksempler, som man må formode er det, Galindo hentyder til (hvorfor ellers sammenstillingen indgangsord/ eksempler), findes ikke. Men hvad skulle man også bruge disse til? At der godt kunne have været et eksempelmateriale på spansk er en anden sag.

Med hensyn til de 25.000 indgangsord forekommer selektionen af disse at være ude af trit med ordbogens titel. Der er i hvert fald en massiv repræsentation af hele ordgrupper, der har med socialsektoren og den juridiske verden at gøre, men ikke med hverken erhvervsliv eller økonomi som sådan. Således optræder indgangsordet fardsel med 17 afledninger, fangsel med 13 afledninger, ungdom med 16 afledninger og arv med 32 afledninger. Dette er ganske vist i overensstemmelse med forordet, men absolut ikke med den indskrænkning, man må forvente i henhold til ordbogens titel. I uoverensstemmelse med både forord og titel er en lang række ord fra andre områder, herunder det almensproglige område. Der kan i flæng nævnes aftagt, alfonseri, bordel, cølibat, diamantbryllup, hasard, narkoman, narkoselage, neurofysiologi, sultegraense, ungkarl...

Ordbogen indeholder derudover en række indgangsord, der er helt værdiløse for den danske bruger.

Det drejer sig for det første om ord, der forekommer yderst sjældent, om overhovedet på nudansk, men som må formodes at være »spejlvendt «, i den forstand at den spanske ækvivalent er et gængs spansk ord, mens det danske indgangsord er en raritet. Eksempler på dette er aldersbetingelse (af: exigencia de edad), afgangsalder (af: edad de jubilación), og erektionsbrev (af: acta de fundación). Sidstnævnte indgangsord er ifølge Dansk Sprognævn et dokument fra 1700/1800-tallet og har således intet at gøre i en moderne dansk-spansk ordbog. 
For det andet drejer det sig om helt ukomplicerede komposita, der kan dannes ved basalt kendskab til spansk grammatik. Her er især de mange sammensætninger med eksport/import eller indførsel/udførsel iøjnefaldende: baconindførsel/baconudførsel, hvede-

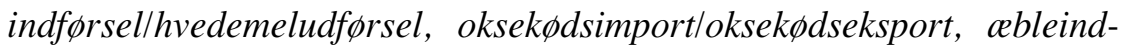
førsel/ableudførsel, ageksport/ agindførsel etc.

Pladsen, som denne lange række af henholdsvis perifere og overflødige ord optager, kunne have været anvendt meget mere fornuftigt.

Dels kunne bredden i emnevalget med fordel være blevet erstattet af en større dybde med hensyn til udvalget af ord fra det deciderede $\emptyset$ konomiske univers, som ifølge titlen burde have stor vægt i ordbogen. I nogle tilfælde kan man være heldig at finde et enkelt overbegreb fra et konkret område, mens alle underbegreberne mangler. Således finder vi indgangsordet betalingsbalance, men ikke betalingsbalancens lфbende poster, kapitalposter. Vi finder inflation, men f.eks. ikke underliggende inflation.

Endvidere kunne der med fordel have været udvist langt større omhu med udarbejdelse af mikrostrukturen, f.eks. med angivelse af anvendelsesområder, kollokationer og eksempler, således som der allerede er peget på i begyndelsen af denne anmeldelse. I denne forbindelse havde det formentlig for Galindo været en smal sag at hente autentiske eksempler fra sit manuskript. Det er altid betryggende for en oversætter at se den pågældende ækvivalent i en sammenhæng i uddrag fra den virkelige verden.

Men udover at optage plads for mere lødige alternativer, rummer de irrelevante, forkerte, etc. indgangsord ingen umiddelbar fare for brugeren. Faren opstår først, når brugeren bevæger sig fra det danske indgangsord til den spanske ækvivalent. Det kræver stor snilde og mange yderligere studier i diverse hjælpematerialer at få ordlisten til at blive en hjælp til en korrekt oversættelse.

Vanskelighederne består for det første i, at ingen ækvivalenter som vi har været inde på før, har områdeangivelser: Se f.eks. følgende artikel:

anmeldelse notificación $f$ :; denuncia $f$; inscripción $f$., declaración $f . / /$

Selv om der altså ved semikolon korrekt er gjort opmærksom på den manglende synonymitet blandt de angivne ækvivalenter, hjælper det ikke brugeren til at træffe det rigtige valg. Det kræver yderligere opslag i andre hjælpemidler. 
Men værre er, at der i masser af tilfælde gives tilsyneladende grønt lys for en synonymiopfattelse, som rent faktisk er forkert. Eksempler: Europaråd: El Consejo de Europa (o Europeo); datterselskab: filial (o sucursal); koncern: grupo de empresas (o consorcio); aspekt: aspecto, apariencia...

I alle tilfælde er der tale om begreber/institutioner af helt forskelligt indhold, hvoraf det tilføjede synonym næsten konsekvent er forkert.

Heldigvis er der ikke så mange synonymiangivelser. I de fleste tilfælde optræder kun en ækvivalent. Det mindsker jo risikoen for fejltagelser af denne art.

Helt sikker kan man dog ikke være, selv om ordlisten kun byder på en enkelt ækvivalent. Der er i Grete Duvås anmeldelse af den franske version peget på klassikerne bruttonationalprodukt og kapitalbalance falske venner både på spansk og fransk, hvor forfatteren i begge tilfælde har lavet en direkte oversættelse af det danske indgangsord. Andre eksempler på fejlagtig ækvivalentangivelse er finanspolitik: política financiera, der burde være política fiscal; handelsbalance: balance comercial, der burde være balanza comercial; kapitalværdi: valor capitalizado, der burde være valor actual neto eller VAN; maksimering: máximo, fijación de máximo, der burde være maximización...

En anden typisk defekt ved ordlisten er ækvivalentangivelser til $\emptyset$ konomiske neologismer som f.eks. valutaslange: sistema monetario europeo que limita la flucturación de las divisas; leasingselskab: sociedad financiera que arrienda og factoring: financiación contra seguridad en el crédito por cobrar.

Det eksisterer faktisk præcise ækvivalenter til de 3 ord. I de to sidste tilfælde anvendes de engelsk udtryk uden videre, og i det første bibeholdes metaforen, dvs. la serpiente.

Som det fremgår, er der snarere end ækvivalenter tale om parafraseringer, der naturligvis kan forstås og dækker det semantiske indhold, men virker helt tåbelige, hvis de integreres i en kontekst.

I det foregående er der på brugerens vegne reklameret over manglende områdeangivelser og glosseringer. Her skal afslutningsvis gives et eksempel på, at også disse kan være farlige. Se den fyldige glossering/ områdeangivelse for »afsætte «:

afsætte salge vender, colocar, dar salida;

a. penge reservar, destinar;

a. imidlertidigt suspender;

a. en minister despedir, revocar, destituir; 
a. en konge destronar;

a. på en tegning marcar;

få afsat casar//

Faren ligger her i de komplikationer, der opstår for brugeren, hvis denne skal forklare, at han har fået afsat sine høns, eller pærer, eller hvad det nu kan være, til Pérez og Co. i Barcelona. Casar betyder nemlig bortgifte.

\section{Konklusion}

Som konklusion kan man sige, at der stadig er et tomrum med hensyn til udgivelse af dansk-spanske ordbøger inden for teknik og økonomi. Galindos initiativ er prisværdigt, men hverken hans Fagordbog eller Erhvervs- og фkonomiordbog lever op til kravene til en moderne fagordbog. Selektionen i begge ordbøger er mangelfuld og tilfældig. Alt for mange ord er ikke medtaget. Ækvivalentangivelserne er upræcise, brugeren får overhovedet ingen hjælp til at finde den rigtige. Alle andre angivelser af sproglig og encyklopædisk art er på det nærmeste ikke-eksisterende. Resultatet er, at Galindos ordbøger kun kan bruges med yderste forsigtighed. De kan i mangel af bedre fungere som et idékatalog, som kan hjælpe til at finde svar på de ønskede spørgsmål. Men oplysningerne må altid efterkontrolleres i andre opslagsværker.

Handsken er kastet... Til arbejdet, spansktalende leksikografer! 